\title{
Glycoprotein K8.1 Antibody
}

National Cancer Institute

\section{Source}

National Cancer Institute. Glycoprotein K8.1 Antibody. NCI Thesaurus. Code C120479.

Any immunog lobulin that recognizes the human herpesvirus 8 glycoprotein K8.1. 